\title{
An Ultrasensitive Biosensor for Detection of Femtogram Levels of the Cancer Antigen AGR2 Using Monoclonal Antibody Modified Screen-Printed Gold Electrodes
}

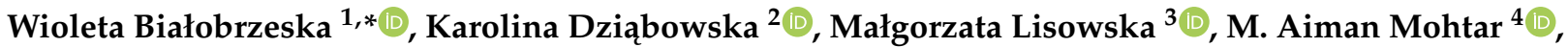 \\ Petr Muller ${ }^{5}$, Borivoj Vojtesek $\left.{ }^{5}{ }^{(}\right)$, Radovan Krejcir ${ }^{5}{ }^{\circ}$, Robert $\mathrm{O}^{\prime}$ Neill $^{6}$, Ted R. Hupp ${ }^{3,7}{ }^{\circ}$, \\ Natalia Malinowska ${ }^{1}\left(\mathbb{D}\right.$, Ewelina Bięga ${ }^{1}{ }^{1}$, Daniel Bigus ${ }^{1}{ }^{\circledR}$, Zofia Cebula ${ }^{1}$, Katarzyna Pala ${ }^{2}$, Elżbieta Czaczyk ${ }^{2}{ }^{\circledR}$, \\ Sabina Żołędowska ${ }^{1}$ and Dawid Nidzworski ${ }^{1}$
}

\section{check for}

updates

Citation: Białobrzeska, W.; Dziąbowska, K.; Lisowska, M.;

Mohtar, M.A.; Muller, P.; Vojtesek, B.; Krejcir, R.; O'Neill, R.; Hupp, T.R.;

Malinowska, N.; et al. An

Ultrasensitive Biosensor for Detection of Femtogram Levels of the Cancer Antigen AGR2 Using Monoclonal Antibody Modified Screen-Printed Gold Electrodes. Biosensors 2021, 11, 184. https://doi.org/10.3390/ bios11060184

Received: 7 April 2021

Accepted: 6 June 2021

Published: 7 June 2021

Publisher's Note: MDPI stays neutral with regard to jurisdictional claims in published maps and institutional affiliations.

Copyright: (c) 2021 by the authors. Licensee MDPI, Basel, Switzerland. This article is an open access article distributed under the terms and conditions of the Creative Commons Attribution (CC BY) license (https:/ / creativecommons.org/licenses/by/ $4.0 /)$.
1 Institute of Biotechnology and Molecular Medicine, 3 Trzy Lipy St., 80-172 Gdansk, Poland; n.malinowska@ibmm.pl (N.M.); e.biega@ibmm.pl (E.B.); d.bigus@ibmm.pl (D.B.); z.cebula@ibmm.pl (Z.C.); sabina.zoledowska@etongroup.eu (S.Ż.); dawid@etongroup.eu (D.N.)

2 SensDx, 14b Postępu St., 02-676 Warszawa, Poland; karolina.dziabowska@gmail.com (K.D.); katarzyna.pala@etongroup.eu (K.P.); ela@etongroup.eu (E.C.)

3 International Centre for Cancer Vaccine Science, University of Gdansk, Kładki 24 St., 80-822 Gdańsk, Poland malgorzata.lisowska@ug.edu.pl (M.L.); ted.hupp@ed.ac.uk (T.R.H.)

4 UKM Medical Centre, UKM Medical Molecular Biology Institute (UMBI), Universiti Kebangsaan Malaysia, Cheras, Kuala Lumpur 56000, Malaysia; m.aimanmohtar@ppukm.ukm.edu.my

5 Research Centre for Applied Molecular Oncology, Masaryk Memorial Cancer Institute, 65653 Brno, Czech Republic; pmuller@post.cz (P.M.); vojtesek@mou.cz (B.V.); radovan.krejcir@mou.cz (R.K.)

6 Cambridge Oesophagogastric Centre, Cambridge University Hospitals NHS Foundation Trust, Cambridge CB2 0QQ, UK; robertoneill@nhs.net

7 Institute of Genetics and Molecular Medicine, University of Edinburgh, Edinburgh EH4 2XR, UK

* Correspondence: w.bialobrzeska@ibmm.pl

\begin{abstract}
The detection of cancer antigens is a major aim of cancer research in order to develop better patient management through early disease detection. Many cancers including prostate, lung, and ovarian secrete a protein disulfide isomerase protein named AGR2 that has been previously detected in urine and plasma using mass spectrometry. Here we determine whether a previously developed monoclonal antibody targeting AGR2 can be adapted from an indirect two-site ELISA format into a direct detector using solid-phase printed gold electrodes. The screen-printed gold electrode was surface functionalized with the anti-AGR2 specific monoclonal antibody. The interaction of the recombinant AGR2 protein and the anti-AGR2 monoclonal antibody functionalized electrode changed its electrochemical impedance spectra. Nyquist diagrams were obtained after incubation in an increasing concentration of purified AGR2 protein with a range of concentrations from $0.01 \mathrm{fg} / \mathrm{mL}$ to $10 \mathrm{fg} / \mathrm{mL}$. In addition, detection of the AGR2 antigen can be achieved from cell lysates in medium or artificial buffer. These data highlight the utility of an AGR2-specific monoclonal antibody that can be functionalized onto a gold printed electrode for a one-step capture and quantitation of the target antigen. These platforms have the potential for supporting methodologies using more complex bodily fluids including plasma and urine for improved cancer diagnostics.
\end{abstract}

Keywords: AGR2 protein; sensor; screen-printed gold electrode; electrochemical impedance spectroscopy

\section{Introduction}

Anterior Gradient-2 (AGR2) was identified as a key protein involved in the assembly of the dorso-anterior ectoderm that forms the cement gland and maintains forebrain integrity [1,2]. AGR2 has since been shown to be an endoplasmic reticulum (ER) localized protein disulfide isomerase superfamily member [3] that is upregulated in a large number of human cancers [4,5]. The cancer associated functions of AGR2 have been inferred from several lines of research including (i) AGR2 drives cement gland production, 
whose function promotes the attachment of the growing epithelium to a solid support [6], (ii) AGR2 can mediate metastatic growth in cancer models [7], and (iii) AGR2 can mediate limb regeneration in amphibia [8]. AGR2 has also been implicated in a diverse range of diseases including asthma [9] and inflammatory bowel disease [10].

AGR2 is over-expressed in a diverse set of human cancers including breast [11], prostate [12], pancreatic [13], liver [14], ovarian [15], esophagus [16-18], and lung cancers [19]. In some cases, AGR2 is secreted allowing remodeling of the pro-metastatic niche $[20,21]$. Accordingly, mass spectrometry and ELISA methodologies have been used to detect AGR2 peptide fragments in urine or plasma [22-26]. In addition to this diagnostic potential of AGR2, inhibition of extracellular AGR2 function using antibodies or peptides suggests therapeutic tools can be developed [27-29]. The range of AGR2 concentrations associated with cancer has been described by Edgell et al. [26]. The paper shows significantly increased concentrations of AGR2 protein in plasma from cancer patients relative to normal controls. Plasma AGR2 concentrations were highest in stages II and III ovarian cancer patients and were similarly elevated in patients with both serous and non-serous tumors. The identification of elevated plasma concentrations of AGR2 may provide a useful biomarker to aid in the discrimination of normal and ovarian cancer patients particularly.

In order to develop new diagnostic assays for AGR2, we had developed a panel of monoclonal antibodies or aptamers that can detect AGR2 and its orthologue AGR3 [15]. These antibodies were functionalized using fluorescent conjugation to develop a twosite ELISA that measures the capture of dimeric AGR2 [30,31]. However, these mass spectrometry approaches and ELISA approaches are limited for rapid diagnostics; the mass spectrometry assay requires significant instrumentation time, costs, and sample preparation whilst the ELISA is a two-step process involving antigen capture and antigen detection.

A novel diagnostic platform has been developed using a gold biosensor that enables the specific detection of a specific antigen at ultralow concentrations using a 'one-step' methodology; a screen-printed gold electrode is surface functionalized with the antibodies of interest and after the absorption of the target antigen, a change in the electrochemical impedance spectra is measured as a function of different features with a limit of detection of $9.3 \mathrm{cfu} / \mathrm{mL}$ defined for a bacterial biomarker [32]. In this report, we aimed to use a gold electrode platform [33] to determine whether the AGR2 antigen can be detected in a 'one-step' process from aqueous samples using the monoclonal antibody validated in clinical tissue using immunohistochemistry [15] and in a two-site ELISA assay [31]. Our data demonstrate that the gold electrode can detect femtogram levels of AGR2 protein in vitro cell culture systems and highlights a platform for further evaluation of AGR2 in liquid biopsies.

\section{Materials and Methods}

\subsection{Reagents and Materials}

For the preparation and modification of electrodes, 99.8\% Ethanol and Sulfuric Acid were provided by Chempur (Piekary Ślaskie, Poland); Phosphate-Buffered Saline (PBS) tablets, Tris Buffered Saline (TBS), 97\% 4-ATP, 25\% GA, and Bovine Serum Albumin (BSA) were provided by Sigma Aldrich (Munich, Germany).

\subsection{Electrochemical Procedures}

The cyclic voltammetry and electrochemical impedance spectroscopy (EIS) were conducted using a Palmsens4 potentiostat/galvanostat system (PalmSens, Houten, The Netherlands) in the standard three electrode configuration. Gold screen-printed electrodes (DropSens, Asturias, Spain) were used as working electrodes, the Pt mesh was used as a counter electrode, while $\mathrm{Ag} / \mathrm{AgCl} / 0.1 \mathrm{M} \mathrm{KCl}$ was used as a reference electrode. All the electrochemical tests were carried out in $1 \mathrm{mM} \mathrm{K}_{3}\left[\mathrm{Fe}(\mathrm{CN})_{6}\right] / \mathrm{K}_{4}\left[\mathrm{Fe}(\mathrm{CN})_{6}\right] / 0.1 \mathrm{M}$ PBS that was previously deaerated. $\mathrm{CV}$ data were collected in the voltage window of -0.65 to $+0.75 \mathrm{~V}$ at the scan rate of $100 \mathrm{mV} / \mathrm{s}$, always in triplicate. 
In case of the electrochemical impedance spectroscopy measurements (EIS), the frequency ranged from $100 \mathrm{kHz}$ to $0.1 \mathrm{~Hz}$ with 50 points. The amplitude of the AC signal was $10 \mathrm{mV}$. Obtained impedance spectra were recorded at the redox reaction formal potential (EF). EF value was calculated based on the redox peaks' positions present on the $\mathrm{CV}$ voltammograms for the screen-printed electrode and approximately equaled $150 \mathrm{mV}$. Each potential was held constant for $60 \mathrm{~s}$ before each measurement to obtain a steady-state condition. Obtained data were subjected to the analysis using an EIS Spectrum Analyzer according to the proposed electric equivalent circuit (EEQC).

\subsection{Biomaterials Preparation and Identification by Reference Methods}

AGR2 protein was purified as reported previously [18]. A549 cells were grown, and lysates made as described previously (see Supplementary, Figure S1) [34]. The AGR2monoclonal antibody was purified using Protein A columns and stored in PBS at a temperature of $4{ }^{\circ} \mathrm{C}$, as described previously [15,31]. The incubation time of the electrode with the target solution was $5 \mathrm{~min}$ for both the positive and negative samples. The H1299 non-small cell lung carcinoma cell line was from ATCC ${ }^{\circledR \circledR}$, Manassas, VA, USA-CRL-5803 ${ }^{\mathrm{TM}}$. The cells were maintained in standard culture conditions $\left(37^{\circ} \mathrm{C}\right.$, humidified atmosphere and $5 \% \mathrm{CO}_{2}$ ) in high glucose Dulbecco's modified Eagle's medium (DMEM; Sigma-Aldrich, St. Louis, MO, USA) supplemented with 10\% fetal bovine serum (Thermo Fisher Scientific, Waltham, MA, USA), 1\% sodium pyruvate (Sigma-Aldrich), and a penicillin/streptomycin antibiotic mixture (Biosera, Nuaille, France).

\subsection{Preparation of the Immunosensor}

The gold electrodes were cleaned with $0.5 \mathrm{M} \mathrm{H}_{2} \mathrm{SO}_{4}$ for $15 \mathrm{~min}$. After each treatment, the gold substrates were rinsed with ethanol and dried under nitrogen flow. Then, the pre-treated gold electrodes were immersed in $0.1 \mathrm{M}$ 4-aminothiophenol in ethanol solution for $12 \mathrm{~h}$ in order to form a self-assembled monolayer (SAM). The substrates were then rinsed with ethanol in order to remove the unbonded thiols. To allow antibodies to attach, the thiol-modified electrodes were treated with $2.5 \%$ glutaraldehyde for $15 \mathrm{~min}$ in a dark place. Next, the gold electrodes were rinsed with water and dried under nitrogen and $10 \mu \mathrm{g} / \mu \mathrm{L}$ of the anti-AGR2 IgG was dropped onto the surface at $37^{\circ} \mathrm{C}$ for $1 \mathrm{~h}$. The excess antibodies were removed by rinsing with PBS. Then, the antibody-modified electrodes were treated with $0.1 \%$ BSA for $30 \mathrm{~min}$, to block the unreacted and non-specific sites. After rinsing with PBS and water, the electrodes were dried under nitrogen. The mechanism for this activation can be seen in Figure 1.

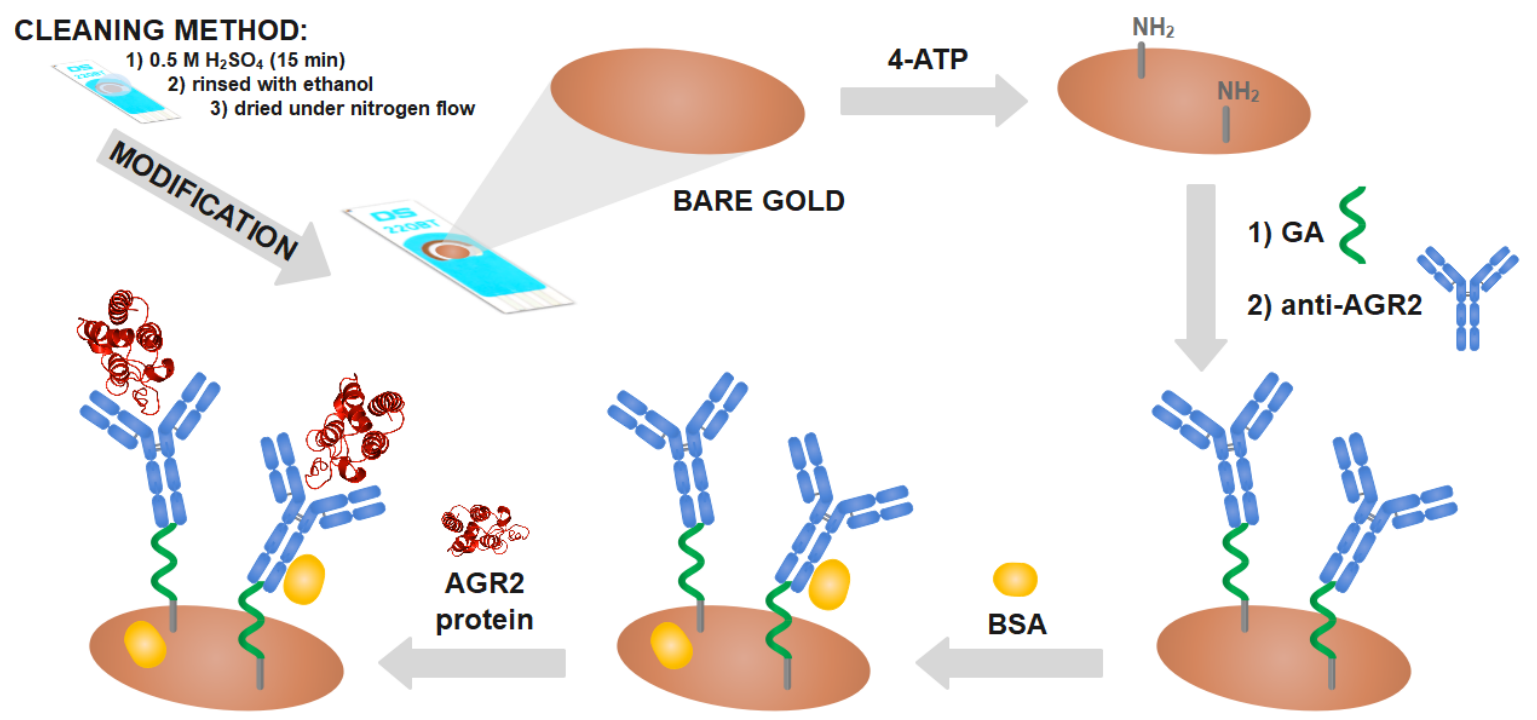

Figure 1. Schematic stages of modified screen-printed gold electrodes. Where 4-ATP stands for 4-aminothiophenol, GA is for glutaraldehyde, anti-AGR2 is for the AGR2 antibody, and BSA is for bovine serum albumin. 


\section{Results}

\subsection{Characterization of the Modified Electrode}

For the electrochemical measurements, the $\mathrm{CV}$ was recorded before and after the deposition of the 4-ATP monolayer. In Figure 2, the $\mathrm{Fe}(\mathrm{II}) / \mathrm{Fe}(\mathrm{III})$ redox peaks exhibit decreased signals after the functionalization of the 4-ATP monolayer. This can be attributed to a decrease in the electron transfer rate that was created by the compactness of the formulated SAMs. After antibody binding, the redox peaks decreased even more due to the decrease in the electron transfer rate. This was due to an increase in the biolayer thickness that was developed on gold surface. The cyclic voltammograms are strongly affected by the deposited layers, the difference between the anodic and cathodic peak potentials does not remain constant, whereas the peak current is modified significantly. The initial characteristic quasi-reversible redox cycle for a bare gold electrode can be seen After its functionalization with BSA, the electron transfer between the redox probe and electrode surface was severely affected and an obvious decrease of the anodic and cathodic peaks was observed.
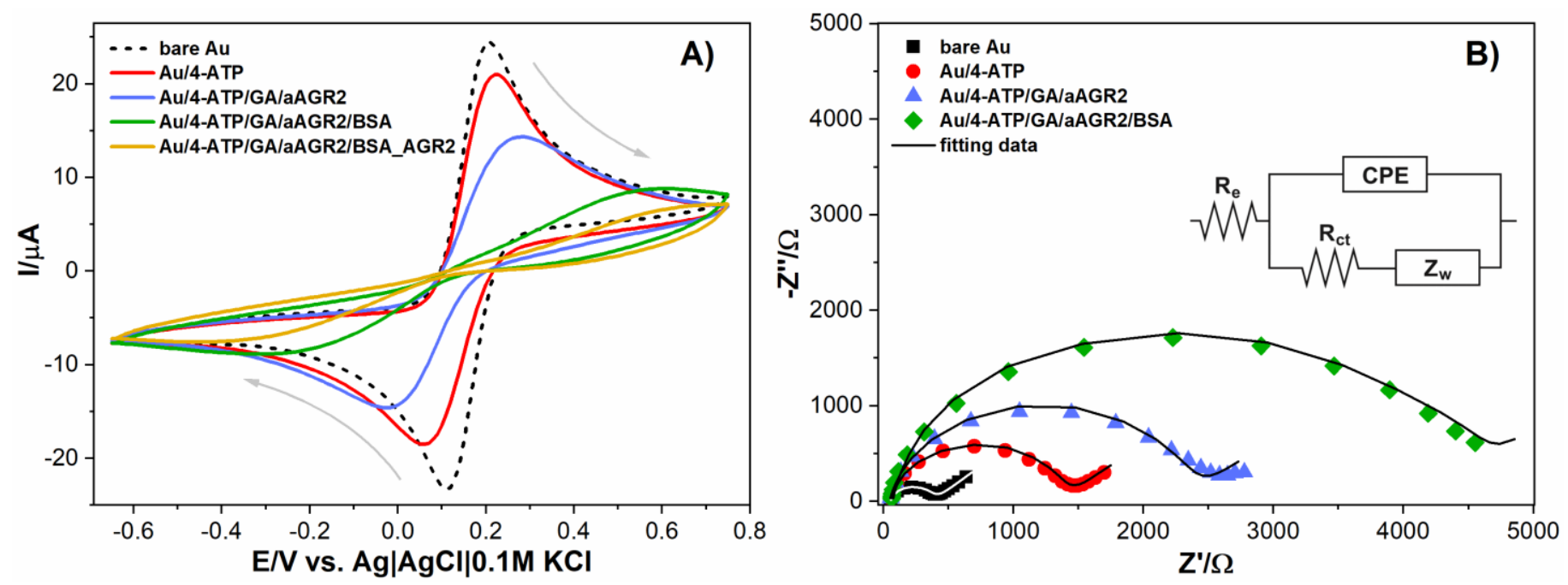

Figure 2. CV (A) and EIS (B) plots recorded for bare and modified Au electrode in $1 \mathrm{mM} \mathrm{Fe}(\mathrm{CN})_{6}^{3-/ 4-} / 0.1 \mathrm{M}$ PBS with scan rate $50 \mathrm{mV} / \mathrm{s}$.

After anti-AGR2 IgG immobilization on the functionalized electrode surface, the peak currents of the redox couple of ferricyanide/ferrocyanide decrease. Immunochemical reaction of protein AGR2 molecules with the antibody film revealed a decrease in the Faradaic response. An increase was observed in the peak-to-peak separation between the cathodic and anodic waves of the redox probe, indicating that the electron-transfer kinetics of ferricyanide/ferrocyanide was obstructed.

Figures $2 \mathrm{~B}$ and $3 \mathrm{~A}$ show the impedance spectra recorded with the EIS technique for a pure gold electrode and after each stage of the modification of its surface and during the detection of the AGR2 protein, respectively. The shape of the impedance spectra in the tested measuring frequency range from $100 \mathrm{kHz}$ to $0.1 \mathrm{~Hz}$ is identical. The EIS spectra consists of one time constant. In the range of the highest and intermediate measurement frequencies, there is a capacitive loop, while at the lowest measurement frequencies, its presence is manifested by the Warburg impedance associated with diffusion control (straight line inclined at an angle of $45^{\circ}$ to the $X$-axis). 


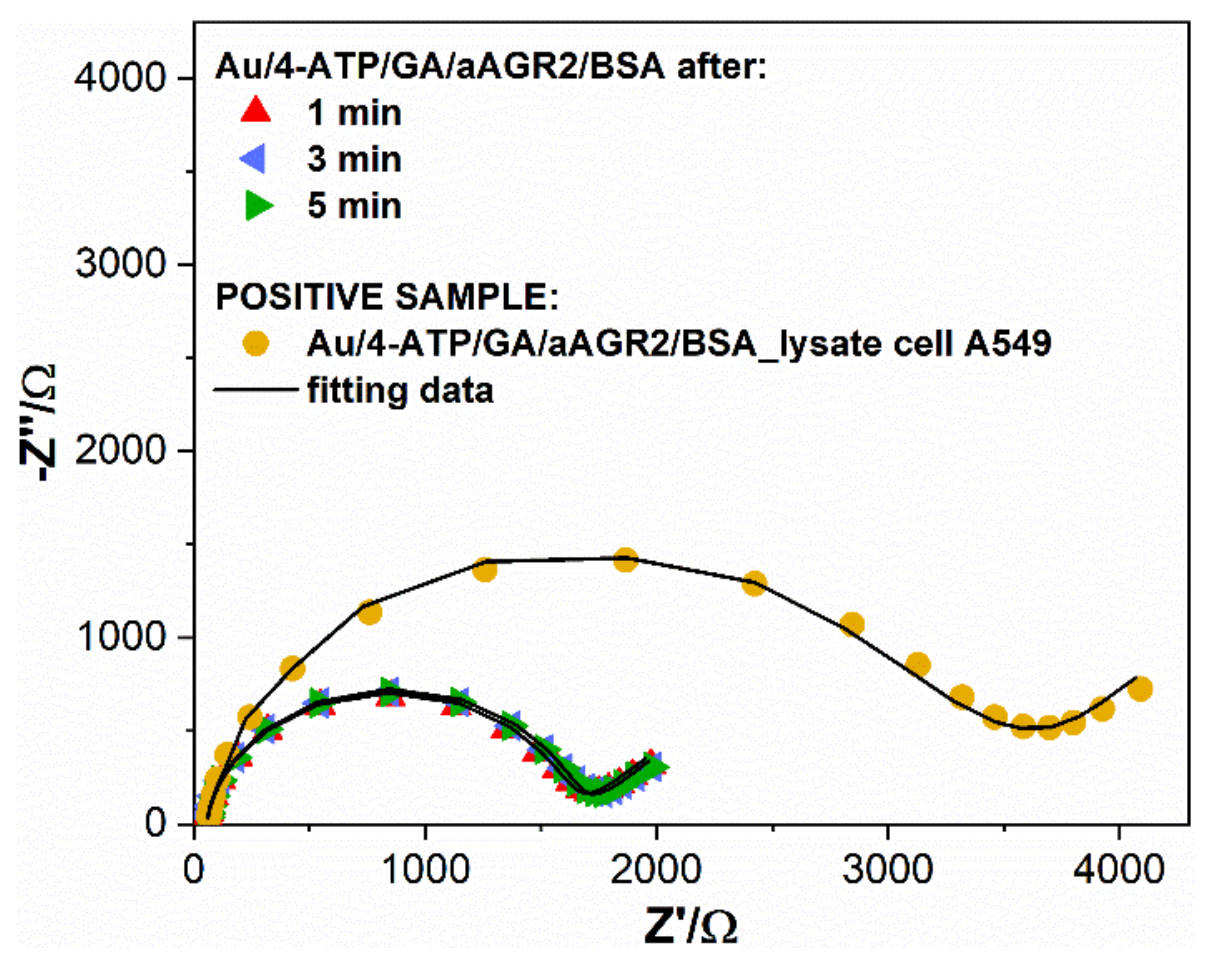

Figure 3. EIS measurement of biosensor response in time, after BSA modification. Registered in $1 \mathrm{mM} \mathrm{K}_{3}\left[\mathrm{Fe}(\mathrm{CN})_{6}\right] / \mathrm{K}_{4}\left[\mathrm{Fe}(\mathrm{CN})_{6}\right] / 0.01 \mathrm{M}$ PBS.

For the analysis of the impedance spectra, the electrical equivalent circuit represented by the Randles circuit $R_{e}\left(C P E\left[R_{c t} W\right]\right)$ [35] was used. $R_{e}$ is the electrolyte resistance, $C P E$ is the constant phase element (represented by $Q$ and $n$ ), $R_{c t}$ is the charge transfer resistance, and $\mathrm{W}$ is the Warburg impedance. The electrical equivalent circuit in the form of a Randles circuit is one of the basic models for describing the electrochemical processes occurring at the electrode/electrolyte interface. It is also widely used for impedance data analysis in electrochemical sensor/biosensor research [33,36-38].

Comparing the spectra recorded for bare screen-printed gold electrode, antibodymodified surface, and after saturation with a BSA solution, we observed a significant increase in resistance $R_{c t}$ values. Such an increase in $R_{c t}$ suggests successful binding between antigen and bare gold surface followed by unspecific binding of BSA to the modified gold substrate.

Stability analysis for the fully functionalized sensor can be seen in Figure 3. The BSA concentration was kept in the same order of magnitude to receive comparable results and impedance spectra were recorded in time. The sensor response was checked in time cycles of 1,3 , and 5 min.

\subsection{Impedance Measurements for the Detection of the AGR2 Protein}

The next stage of verification of the modified screen-printed gold electrode as a potential biosensor includes subsequent incubation in diluted solution of AGR2 protein and recording the electrode response with electrochemical impedance spectroscopy (Figure 4A). Here, the charge transfer resistance $\left(\mathrm{R}_{\mathrm{ct}}\right)$ increases gradually as the protein concentration increases after consecutive incubations. This was made from $0.01 \mathrm{fg} / \mathrm{mL}$ to $1 \mathrm{fg} / \mathrm{mL}$. Table 1 presents the resistance values with incubation. 

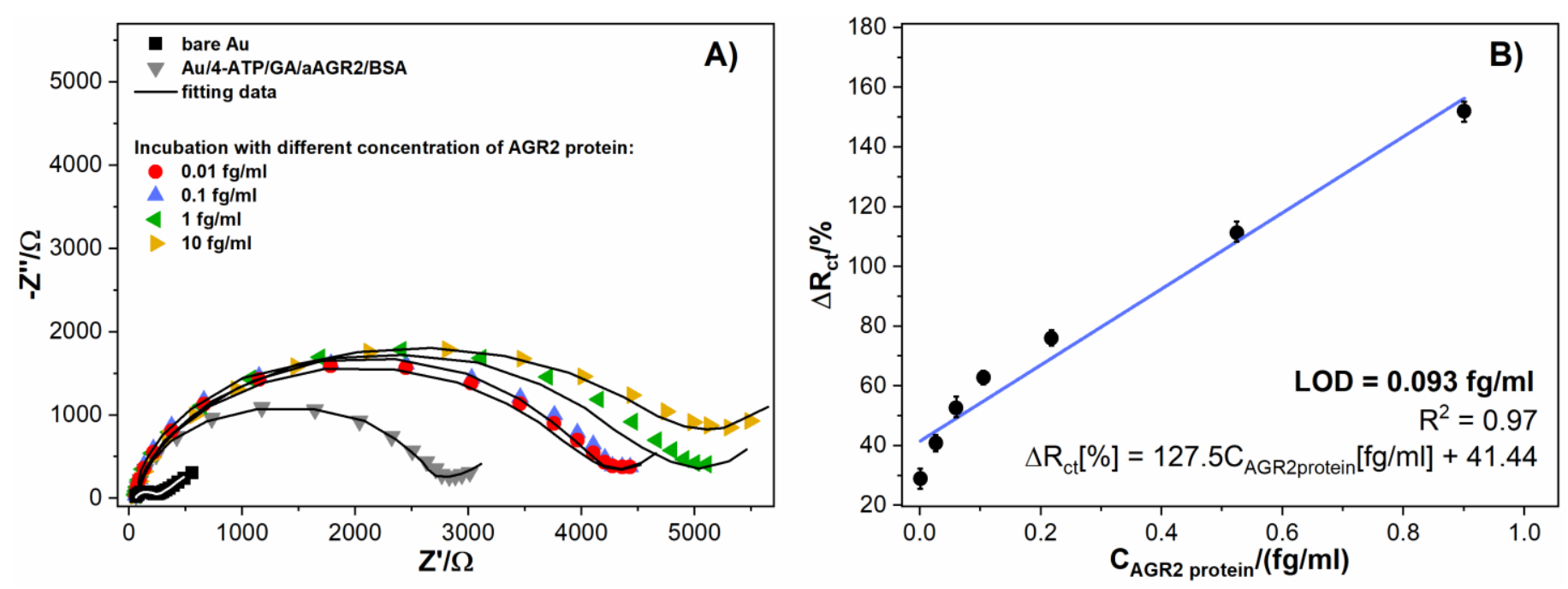

Figure 4. (A) Impedance spectra of Au/4-ATP/GA/aAGR2/BSA electrode after incubating in solutions with different protein concentrations recorded in $1 \mathrm{mM} \mathrm{K}_{3} \mathrm{Fe}(\mathrm{CN})_{6} / \mathrm{K}_{4}\left[\mathrm{Fe}(\mathrm{CN})_{6}\right] / 0.01 \mathrm{M} \mathrm{PBS}$, (B) The relation between the sensor response expressed as $\mathrm{R}_{\mathrm{ct}}$ change $\left(\Delta \mathrm{R}_{\mathrm{ct}}\right)$ and the protein concentration. Registered in $1 \mathrm{mM} \mathrm{K} \mathrm{K}_{3}\left[\mathrm{Fe}(\mathrm{CN})_{6}\right] / \mathrm{K}_{4}\left[\mathrm{Fe}(\mathrm{CN})_{6}\right] / 0.01 \mathrm{M} \mathrm{PBS}$. Error bars denote confidence interval $(\alpha=0.05, \mathrm{n}=3)$.

Table 1. The values of the elements obtained using EEQC - unmodified screen-printed gold electrode and screen-printed gold electrode modified with various concentration of protein.

\begin{tabular}{|c|c|c|c|c|c|}
\hline Sample & $\mathbf{R}_{\mathrm{e}}[\Omega]$ & $\mathrm{CPE}\left[\mu \Omega^{-1} s^{n}\right]$ & $\mathrm{n}$ & $\mathbf{R}_{\mathrm{ct}}[\Omega]$ & $\mathrm{AW}\left[\Omega s^{-0.5}\right]$ \\
\hline bare $\mathrm{Au}$ & 50.058 & 2.62 & 0.915 & 315.57 & 3.893 \\
\hline $\mathrm{Au} / 4-\mathrm{ATP} / \mathrm{GA} / \mathrm{aAGR} 2$ & 49.896 & 0.90 & 0.951 & 2223.9 & 701.63 \\
\hline $\mathrm{Au} / 4-\mathrm{ATP} / \mathrm{GA} / \mathrm{aAGR} 2 / \mathrm{BSA}$ & 53.244 & 0.98 & 0.939 & 2259.2 & 824.3 \\
\hline $\mathrm{Au} / 4-\mathrm{ATP} / \mathrm{GA} / \mathrm{aAGR} 2 / \mathrm{BSA}$ _protein AGR2 $0.01 \mathrm{fg} / \mathrm{mL}$ & 48.971 & 1.06 & 0.920 & 3449.3 & 1266.8 \\
\hline $\mathrm{Au} / 4-\mathrm{ATP} / \mathrm{GA} / \mathrm{aAGR} 2 / \mathrm{BSA}^{-1}$ protein AGR2 $0.1 \mathrm{fg} / \mathrm{mL}$ & 50.617 & 1.09 & 0.920 & 3704.4 & 1308.4 \\
\hline $\mathrm{Au} / 4-\mathrm{ATP} / \mathrm{GA} / \mathrm{aAGR} 2 / \mathrm{BSA}$ _protein AGR2 $1 \mathrm{fg} / \mathrm{mL}$ & 67.882 & 1.18 & 0.920 & 4887.6 & 1658.3 \\
\hline $\mathrm{Au} / 4-\mathrm{ATP} / \mathrm{GA} / \mathrm{aAGR} 2 / \mathrm{BSA}$ _protein AGR2 $10 \mathrm{fg} / \mathrm{mL}$ & 68.882 & 1.20 & 0.920 & 5790,9 & 1667.6 \\
\hline
\end{tabular}

Figure 4B displays the impedance changes for the developed immunosensor incubated with different AGR2 protein concentrations. The tested gold impedance immunosensor was characterized by a linear response from $0.001 \mathrm{fg} / \mathrm{mL}$ to $0.900 \mathrm{fg} / \mathrm{mL}$. The linear regression equation can be expressed as $\Delta \mathrm{R}_{\mathrm{ct}}[\%]=127.5 \mathrm{C}_{\mathrm{AGR} 2 \text { protein }}[\mathrm{fg} / \mathrm{mL}]+41.44$ with a correlation coefficient of $\mathrm{R}^{2}=0.97$. The values of relative standard deviation were calculated and ranged from $4.3 \%$ to $6.9 \%$. The sensitivity is $127.5 \%(\mathrm{fg} / \mathrm{mL})^{-1}$. The obtained limit of detection (LOD) for the presented immunosensor equals $0.093 \mathrm{fg} / \mathrm{mL}(\mathrm{S} / \mathrm{N}=3)$. Linearity ranges and LODs of different methods for AGR2 protein detection are presented and compared in Table 2.

After the confirmation of the IgG anchor and AGR2 protein detection onto the gold surface, the transferability of the proposed substrate was examined on a biological sample where AGR2 is present at low levels in crude lysates. For this experimental step, lysate from A549 cells was chosen, which expresses AGR2 protein [35]. Negative controls of PBS and medium containing lysis buffer were also evaluated. The samples' incubations on the $\mathrm{Au} / 4-\mathrm{ATP} / \mathrm{GA} / \mathrm{aAGR} 2 / \mathrm{BSA}$ modified electrodes lasted $5 \mathrm{~min}$ and the unbound particles were flushed away with deionized water. Next, the EIS spectra were recorded. For each sample, a separate substrate was used. The complex detection with a mix of both positive and negative samples on the same electrode was also examined. 
Table 2. The comparison of AGR2 proteindetection methods using electrochemical techniques on the various substrate.

\begin{tabular}{|c|c|c|c|c|c|}
\hline Detection Substrate & Target Molecules & Turnaround Time & Sensitivity & Limit of Detection & Reference \\
\hline $\begin{array}{c}\text { ITO } \\
(\mathrm{CV}, \mathrm{DPV}, \mathrm{EIS})\end{array}$ & CA15-3 & $15 \mathrm{~min}$ & $13 \mu \mathrm{L}^{-1} \mathrm{ng} / \mathrm{cm}^{-2}$ & $0.001 \mathrm{ng} / \mathrm{mL}$ & {$[39,40]$} \\
\hline $\begin{array}{l}\text { FTO } \\
(\mathrm{CV})\end{array}$ & $\begin{array}{c}\text { plasminogen } \\
\text { activator receptor }\end{array}$ & $35 \mathrm{~s}$ & - & $4.8 \mathrm{fM}$ & {$[40,41]$} \\
\hline $\begin{array}{l}\text { Polypyrrole-gold nanocomposite } \\
\text { (DPV) }\end{array}$ & CA125 & $80 \mathrm{~min}$ & - & $30.9 \mathrm{ng} / \mathrm{mL}$ & [42] \\
\hline $\begin{array}{l}\text { AuSPE } \\
\text { (EIS, DPV) }\end{array}$ & MCF-7 & $91 \mathrm{~s}$ & $77 \mathrm{EVs} / \mathrm{mL}$ & 77 particles $/ \mathrm{mL}$ & {$[40,43]$} \\
\hline $\begin{array}{c}\text { SPCE } \\
(\mathrm{CV}, \mathrm{EIS})\end{array}$ & MUC1 & $45 \mathrm{~min}$ & - & $0.02 \mathrm{U} / \mathrm{mL}$ & {$[40,44]$} \\
\hline $\begin{array}{c}\text { GCE } \\
\text { (DPV, Polylysine modification) }\end{array}$ & AGR2 & $90 \mathrm{~min}$ & - & $2.3 \mathrm{fM}$ & {$[40,45]$} \\
\hline $\begin{array}{c}\text { GE } \\
\text { (DPV, AgNPs modification) }\end{array}$ & AR-42 & $90 \mathrm{~min}$ & - & 6 cells $/ \mathrm{mL}$ & {$[40,46]$} \\
\hline $\begin{array}{c}\mathrm{Au} \\
\text { (EIS) }\end{array}$ & AGR2 & $3 \mathrm{~min}$ & $127.5 \%(\mathrm{fg} / \mathrm{mL})^{-1}$ & $0.093 \mathrm{fg} / \mathrm{mL}$ & this work \\
\hline
\end{tabular}

No crucial changes were observed for separate measurements of PBS and control medium. The electrodes' impedimetric characteristic stayed practically unchanged (Figure 5). For the measurements of the mix of negative samples and lysate, representative data are presented in Figure 5A, which shows impedance changes of the gold electrode during the modification steps of the sensor and antigen detection. The substantial impedance increase was observed after anti-AGR2 antibodies were linked and BSA free-sites were blocked, confirming the presence of a densely packed protein biolayer. The incubation of the Au/4-ATP/GA/aAGR2/BSA modified electrode with cell lysate A549 resulted in successive impedance increases compared to the ready biosensor (Figure 5B). After the AGR2 protein detection from the lysate, the same electrode was flushed with water and incubated with PBS buffer to exclude unspecific interactions. The impedance decreased slightly, which might be attributed to some disorder of the structure during electrode displacement and rinsing. Most importantly, the $\mathrm{R}_{\mathrm{ct}}$ did not increase after incubation with PBS, which would indicate false positive antibodies-antigen interactions.
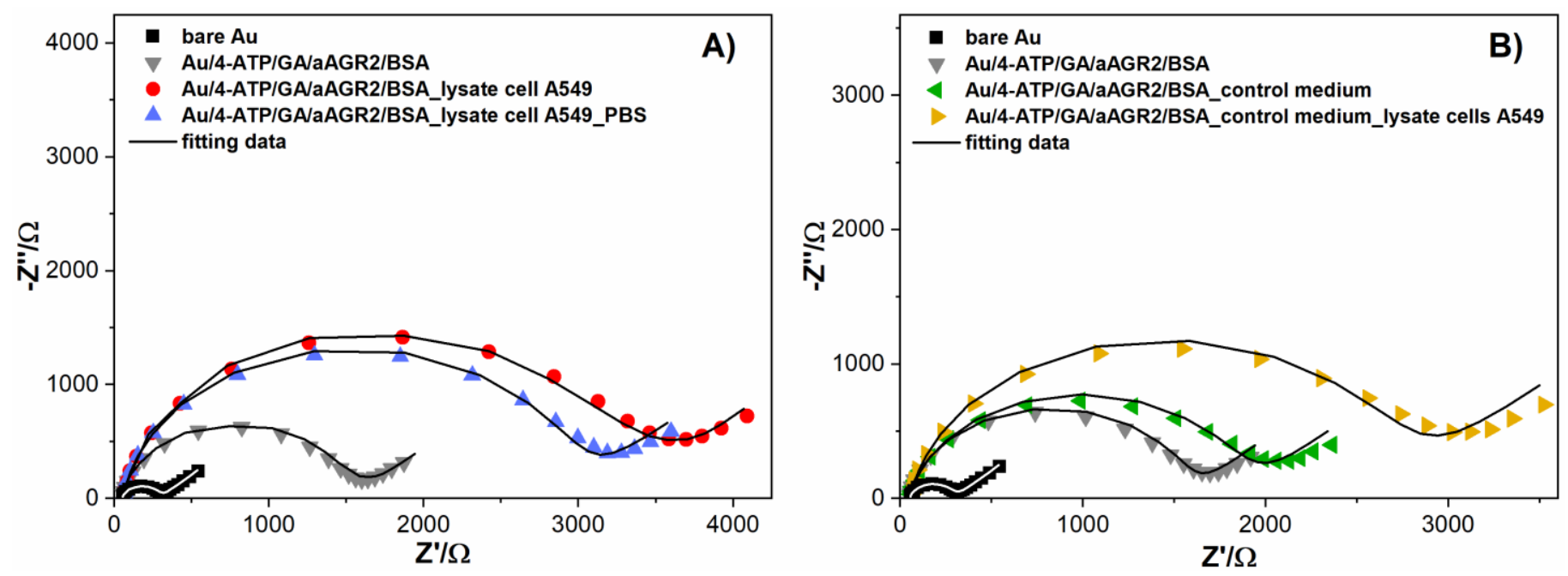

Figure 5. Nyquist plots of impedance spectra for bare and modified Au electrodes in $1 \mathrm{mM} \mathrm{K}_{3} \mathrm{Fe}(\mathrm{CN})_{6} / 0.1 \mathrm{M} \mathrm{PBS}$ at frequencies ranging between $100 \mathrm{~Hz}$ and $0.1 \mathrm{kHz}$. (A) electrode after incubating in solution with lysate cell A549 and PBS (B) electrode after incubating in solution with control medium and lysate cell A549. 
As further controls, Figure 5B highlights the impedance changes of the gold electrode during modification steps of the sensor and antigen detection. This time, after proper modification steps, the BSA saturated electrode was incubated with a negative controlmedium. An increase in impedance was observed, however negligible, compared to the detection of the AGR2 protein in the lowest concentration of $0.01 \mathrm{fg} / \mathrm{mL}$ (Figure $5 \mathrm{~B}$ ). The $\mathrm{R}_{\mathrm{ct}}$ value increased $57 \%$ (from $942.41 \Omega$ to $1667.6 \Omega$ ). On the second step, the electrode was rinsed with water and incubated again, this time with A549 cell lysate. The above results confirmed the specificity of the developed sensor in the presence of negative buffers and positive cell lysate samples. The detailed parameters for both sensors (Figures $5 \mathrm{~A}$ and $4 \mathrm{~B}$ ) with the chosen equivalent circuit were summarized in Table 1.

\subsection{Biosensor Selectivity, Repeatability and Stability Studies}

PBS, TBS, lysate buffer, and H1299 cells were used as negative samples to investigate the selectivity of the immunosensor. As positive samples we used AGR2 protein and A549 cell lysates containing the AGR2 protein (Supplementary Figure S1). The negative samples' concentration was kept in the same order of magnitude to receive comparable results. Next, they were applied to the modified electrode separately. After 5 min incubation, the EIS spectra were recorded. According to the assumptions, there was no significant increase in the value of $R_{c t}$ parameter for the negative samples: PBS, TBS, lysate buffer, and $\mathrm{H} 1299$ cells. Additionally, these changes did not exceed $10 \%$ (Figure 6). Compared to the $\% \mathrm{R}_{\mathrm{ct}}$ change in the presence of positive AGR2 protein and A549 cells, the negative samples were proved to give no cross-reactivity, indicating that the proposed method has high selectivity for the detection of protein AGR2. The percentage of changes in the charge transfer resistance parameter for positive samples was noticeably larger and ranged from $117.11 \%$ to $124 \%$. It can be concluded from the measurements that the antibodies used in these studies properly bind to each species of pathogen for which the sensor was designed. All measurements were repeated on a series of three electrodes to confirm the lack of influence of negative samples on further measurements. Furthermore, the relative standard deviations (RSD) took values from 2 to $10 \%$, which indicates the high stability of the proposed system.

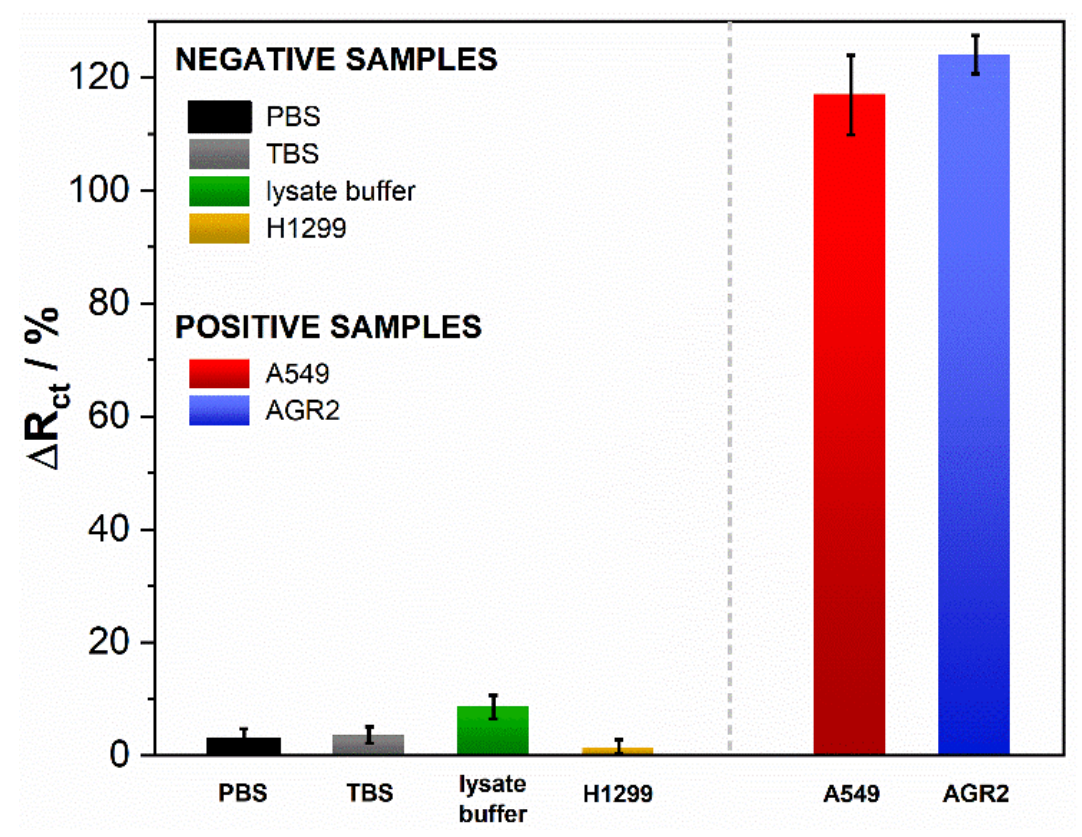

Figure 6. The plot of $\mathrm{R}_{\mathrm{ct}}$ percentage changes as a response of the biosensor after incubation with negative and positive samples. The error bars show the standard deviations for three individual experiments. 


\section{Conclusions}

In summary, we have reported the extended investigation of an impedimetric immunosensor for AGR2 protein detection. The mechanism is based on the EIS spectra recorded at antibody-modified gold electrodes. These data build on our prior research to develop a gold electrode platform [33] but in this report we apply this to a monoclonal antibody that targets a cancer antigen, AGR2. The obtained limit of detection (LOD) for the presented immunosensor equals $0.093 \mathrm{fg} / \mathrm{mL}(\mathrm{S} / \mathrm{N}=3)$. The advantage of this 'onestep' diagnostic assay relative to an ELISA or mass spectrometry is rapid and sensitive measurement of antigen binding. This provides a proof of concept that we intend to use to develop clinical trials with plasma in order to determine whether AGR2 antigen detection in patient fluid provides any prognostic indicator.

Supplementary Materials: The following are available online at https:/ /www.mdpi.com/article/ 10.3390/bios11060184/s1, Figure S1: Immunohistochemical expression of AGR2 protein in A549 cells. The A549 cells were fixed with 4\% ( $v / v)$ paraformaldehyde in PBS at RT for $15 \mathrm{~min}$, washed with PBS three times, and permeabilized using $0.25 \%$ triton X-100 in PBS at RT for $10 \mathrm{~min}$. Then, the cells were again washed with PBS three times and blocked with 3\% BSA in PBS for $1 \mathrm{~h}$. The primary antibody was incubated at appropriate dilution (typically 1:1000) overnight at $4{ }^{\circ} \mathrm{C}$. Alexa Fluor 488 goat anti-mouse (Invitrogen, USA) secondary antibody was incubated at RT for $1 \mathrm{~h}$. Coverslips were washed three times with PBS in between each step. Cells were incubated in DAPI (image B and C) (Invitrogen, USA) diluted at 1:10,000 with $\mathrm{dH} 2 \mathrm{O}$ for $5 \mathrm{~min}$ to stain the nucleus. An additional 3 washes with dH2O for 5 min were performed. A single drop of Fluorescence Mounting Medium (S3023, Dako, Denmark) was used to mount the cells on the slide. The fluorescent signal (image A and C) was detected using a Zeiss Axioplan 2 microscope (63× or $100 \times$ oil immersion objective). Images were acquired by Micro-Manager 1.4 software. Images were processed in ImageJ 2.0 software.

Author Contributions: Conceptualization, W.B. and T.R.H.; investigation, W.B., K.D., and E.B., writing-original draft preparation, W.B., B.V., K.D., T.R.H., N.M., E.B., D.B., M.L., and M.A.M.; methodology, P.M., R.K., T.R.H., N.M., E.B., D.B., E.C., and Z.C.; writing-review and editing, W.B, P.M., K.D., and R.O.; supervision, D.N.; project administration, S.Ż. and K.P.; funding acquisition, D.N.; formal analysis, B.V., R.O., and T.R.H. All authors have read and agreed to the published version of the manuscript.

Funding: This work was supported with the European Regional Development Fund-Project ENOCH (No. CZ.02.1.01/0.0/0.0/16_019/0000868), MH CZ-DRO (MMCI, 00209805); the BBSRC RASOR consortium (BB/C511599/1; United Kingdom); The International Centre for Cancer Vaccine Science project carried out within the International Research Agendas program of the Foundation for Polish Science co-financed by the European Union under the European Regional Development Fund TECHMATSTRATEG 1/347324/12/NCBR/2017. This research was funded by the First TEAM program of the Foundation for Polish Science POIR.04.04.00-00-1644/18.

Institutional Review Board Statement: Not applicable.

Informed Consent Statement: Not applicable.

Conflicts of Interest: The authors declare no conflict of interest. The funders had no role in the design of the study; in the collection, analyses, or interpretation of data; in the writing of the manuscript, or in the decision to publish the results.

\section{References}

1. Aberger, F.; Weidinger, G.; Grunz, H.; Richter, K. Anterior Specification of Embryonic Ectoderm: The Role of the Xenopus Cement Gland-Specific Gene XAG-2. Mech. Dev. 1998, 72, 115-130. [CrossRef]

2. Thompson, D.A.; Weigel, R.J. HAG-2, the Human Homologue of TheXenopus LaevisCement Gland Gene XAG-2, Is Coexpressed with Estrogen Receptor in Breast Cancer Cell Lines. Biochem. Biophys. Res. Commun. 1998, 251, 111-116. [CrossRef]

3. Persson, S.; Rosenquist, M.; Knoblach, B.; Khosravi-Far, R.; Sommarin, M.; Michalak, M. Diversity of the Protein Disulfide Isomerase Family: Identification of Breast Tumor Induced Hag2 and Hag3 as Novel Members of the Protein Family. Mol. Phylogenet. Evol. 2005, 36, 734-740. [CrossRef]

4. Brychtova, V.; Mohtar, A.; Vojtesek, B.; Hupp, T.R. Mechanisms of Anterior Gradient-2 Regulation and Function in Cancer. Semin. Cancer Biol. 2015, 33, 16-24. [CrossRef] [PubMed] 
5. Tian, S.; Tao, K.; Hu, J.; Liu, Z.; Ding, X.; Chu, Y.; Cui, J.; Shuai, X.; Gao, J.; Cai, K.; et al. The Prognostic Value of AGR2 Expression in Solid Tumours: A Systematic Review and Meta-Analysis. Sci. Rep. 2017, 7, 15500. [CrossRef] [PubMed]

6. Sive, H.L.; Hattori, K.; Weintraub, H. Progressive Determination during Formation of the Anteroposterior Axis in Xenopus Laevis. Cell 1989, 58, 171-180. [CrossRef]

7. Patel, P.; Clarke, C.; Barraclough, D.L.; Jowitt, T.A.; Rudland, P.S.; Barraclough, R.; Lian, L.-Y. Metastasis-Promoting Anterior Gradient 2 Protein Has a Dimeric Thioredoxin Fold Structure and a Role in Cell Adhesion. J. Mol. Biol. 2013, 425, 929-943. [CrossRef]

8. Kumar, A.; Godwin, J.W.; Gates, P.B.; Garza-Garcia, A.A.; Brockes, J.P. Molecular Basis for the Nerve Dependence of Limb Regeneration in an Adult Vertebrate. Science 2007, 318, 772-777. [CrossRef]

9. Di Valentin, E.; Crahay, C.; Garbacki, N.; Hennuy, B.; Guéders, M.; Noël, A.; Foidart, J.-M.; Grooten, J.; Colige, A.; Piette, J.; et al. New Asthma Biomarkers: Lessons from Murine Models of Acute and Chronic Asthma. Am. J. Physiol. Lung Cell Mol. Physiol. 2009, 296, L185-L197. [CrossRef] [PubMed]

10. Maurel, M.; Obacz, J.; Avril, T.; Ding, Y.-P.; Papadodima, O.; Treton, X.; Daniel, F.; Pilalis, E.; Hörberg, J.; Hou, W.; et al. Control of Anterior GRadient 2 (AGR2) Dimerization Links Endoplasmic Reticulum Proteostasis to Inflammation. EMBO Mol. Med. 2019, 11. [CrossRef]

11. Fritzsche, F.R.; Dahl, E.; Pahl, S.; Burkhardt, M.; Luo, J.; Mayordomo, E.; Gansukh, T.; Dankof, A.; Knuechel, R.; Denkert, C.; et al. Prognostic Relevance of AGR2 Expression in Breast Cancer. Clin. Cancer Res. 2006, 12, 1728-1734. [CrossRef] [PubMed]

12. Chanda, D.; Lee, J.H.; Sawant, A.; Hensel, J.A.; Isayeva, T.; Reilly, S.D.; Siegal, G.P.; Smith, C.; Grizzle, W.; Singh, R.; et al. Anterior Gradient Protein-2 Is a Regulator of Cellular Adhesion in Prostate Cancer. PLoS ONE 2014, 9, e89940. [CrossRef] [PubMed]

13. Dumartin, L.; Alrawashdeh, W.; Trabulo, S.M.; Radon, T.P.; Steiger, K.; Feakins, R.M.; di Magliano, M.P.; Heeschen, C.; Esposito, I.; Lemoine, N.R.; et al. ER Stress Protein AGR2 Precedes and Is Involved in the Regulation of Pancreatic Cancer Initiation. Oncogene 2017, 36, 3094-3103. [CrossRef]

14. Lepreux, S.; Bioulac-Sage, P.; Chevet, E. Differential Expression of the Anterior Gradient Protein-2 Is a Conserved Feature during Morphogenesis and Carcinogenesis of the Biliary Tree. Liver Int. 2011, 31, 322-328. [CrossRef] [PubMed]

15. Gray, T.A.; MacLaine, N.J.; Michie, C.O.; Bouchalova, P.; Murray, E.; Howie, J.; Hrstka, R.; Maslon, M.M.; Nenutil, R.; Vojtesek, B.; et al. Anterior Gradient-3: A Novel Biomarker for Ovarian Cancer That Mediates Cisplatin Resistance in Xenograft Models. J. Immunol. Methods 2012, 378, 20-32. [CrossRef]

16. Pohler, E.; Craig, A.L.; Cotton, J.; Lawrie, L.; Dillon, J.F.; Ross, P.; Kernohan, N.; Hupp, T.R. The Barrett's Antigen Anterior Gradient-2 Silences the P53 Transcriptional Response to DNA Damage. Mol. Cell Proteom. 2004, 3, 534-547. [CrossRef]

17. O'Neill, J.R.; Pak, H.-S.; Pairo-Castineira, E.; Save, V.; Paterson-Brown, S.; Nenutil, R.; Vojtěšek, B.; Overton, I.; Scherl, A.; Hupp, T.R. Quantitative Shotgun Proteomics Unveils Candidate Novel Esophageal Adenocarcinoma (EAC)-Specific Proteins. Mol. Cell Proteom. 2017, 16, 1138-1150. [CrossRef] [PubMed]

18. Mohtar, M.A.; Hernychova, L.; O’Neill, J.R.; Lawrence, M.L.; Murray, E.; Vojtesek, B.; Hupp, T.R. The Sequence-Specific PeptideBinding Activity of the Protein Sulfide Isomerase AGR2 Directs Its Stable Binding to the Oncogenic Receptor EpCAM. Mol. Cell Proteom. 2018, 17, 737-763. [CrossRef]

19. Shriwash, N.; Singh, P.; Arora, S.; Ali, S.M.; Ali, S.; Dohare, R. Identification of Differentially Expressed Genes in Small and Non-Small Cell Lung Cancer Based on Meta-Analysis of MRNA. Heliyon 2019, 5, e01707. [CrossRef]

20. Fessart, D.; Domblides, C.; Avril, T.; Eriksson, L.A.; Begueret, H.; Pineau, R.; Malrieux, C.; Dugot-Senant, N.; Lucchesi, C.; Chevet, E.; et al. Secretion of Protein Disulphide Isomerase AGR2 Confers Tumorigenic Properties. Elife 2016, 5, e13887. [CrossRef]

21. Obacz, J.; Sommerova, L.; Sicari, D.; Durech, M.; Avril, T.; Iuliano, F.; Pastorekova, S.; Hrstka, R.; Chevet, E.; Delom, F.; et al. Extracellular AGR3 Regulates Breast Cancer Cells Migration via Src Signaling. Oncol. Lett. 2019, 18, 4449-4456. [CrossRef]

22. Ho, M.E.; Quek, S.-I.; True, L.D.; Seiler, R.; Fleischmann, A.; Bagryanova, L.; Kim, S.R.; Chia, D.; Goodglick, L.; Shimizu, Y.; et al. Bladder Cancer Cells Secrete While Normal Bladder Cells Express but Do Not Secrete AGR2. Oncotarget 2016, 7, 15747-15756. [CrossRef]

23. Shi, T.; Gao, Y.; Quek, S.I.; Fillmore, T.L.; Nicora, C.D.; Su, D.; Zhao, R.; Kagan, J.; Srivastava, S.; Rodland, K.D.; et al. A Highly Sensitive Targeted Mass Spectrometric Assay for Quantification of AGR2 Protein in Human Urine and Serum. J. Proteome Res. 2014, 13, 875-882. [CrossRef]

24. Wayner, E.A.; Quek, S.-I.; Ahmad, R.; Ho, M.E.; Loprieno, M.A.; Zhou, Y.; Ellis, W.J.; True, L.D.; Liu, A.Y. Development of an ELISA to Detect the Secreted Prostate Cancer Biomarker AGR2 in Voided Urine. Prostate 2012, 72, 1023-1034. [CrossRef] [PubMed]

25. Kani, K.; Malihi, P.D.; Jiang, Y.; Wang, H.; Wang, Y.; Ruderman, D.L.; Agus, D.B.; Mallick, P.; Gross, M.E. Anterior Gradient 2 (AGR2): Blood-Based Biomarker Elevated in Metastatic Prostate Cancer Associated with the Neuroendocrine Phenotype. Prostate 2013, 73, 306-315. [CrossRef]

26. Edgell, T.A.; Barraclough, D.L.; Rajic, A.; Dhulia, J.; Lewis, K.J.; Armes, J.E.; Barraclough, R.; Rudland, P.S.; Rice, G.E.; Autelitano, D.J. Increased Plasma Concentrations of Anterior Gradient 2 Protein Are Positively Associated with Ovarian Cancer. Clin. Sci. (Lond.) 2010, 118, 717-725. [CrossRef]

27. Liu, A.Y.; Kanan, A.D.; Radon, T.P.; Shah, S.; Weeks, M.E.; Foster, J.M.; Sosabowski, J.K.; Dumartin, L.; Crnogorac-Jurcevic, T. AGR2, a Unique Tumor-Associated Antigen, Is a Promising Candidate for Antibody Targeting. Oncotarget 2019, 10, 4276-4289. [CrossRef] 
28. Negi, H.; Merugu, S.B.; Mangukiya, H.B.; Li, Z.; Zhou, B.; Sehar, Q.; Kamle, S.; Yunus, F.-U.-N.; Mashausi, D.S.; Wu, Z.; et al. Anterior Gradient-2 Monoclonal Antibody Inhibits Lung Cancer Growth and Metastasis by Upregulating P53 Pathway and without Exerting Any Toxicological Effects: A Preclinical Study. Cancer Lett. 2019, 449, 125-134. [CrossRef] [PubMed]

29. Garri, C.; Howell, S.; Tiemann, K.; Tiffany, A.; Jalali-Yazdi, F.; Alba, M.M.; Katz, J.E.; Takahashi, T.T.; Landgraf, R.; Gross, M.E.; et al. Identification, Characterization and Application of a New Peptide against Anterior Gradient Homolog 2 (AGR2). Oncotarget 2018, 9, 27363-27379. [CrossRef] [PubMed]

30. Murray, E.; McKenna, E.O.; Burch, L.R.; Dillon, J.; Langridge-Smith, P.; Kolch, W.; Pitt, A.; Hupp, T.R. Microarray-Formatted Clinical Biomarker Assay Development Using Peptide Aptamers to Anterior Gradient-2. Biochemistry 2007, 46, 13742-13751. [CrossRef]

31. Gray, T.A.; Murray, E.; Nowicki, M.W.; Remnant, L.; Scherl, A.; Muller, P.; Vojtesek, B.; Hupp, T.R. Development of a Fluorescent Monoclonal Antibody-Based Assay to Measure the Allosteric Effects of Synthetic Peptides on Self-Oligomerization of AGR2 Protein. Protein Sci. 2013, 22, 1266-1278. [CrossRef]

32. Nidzworski, D.; Siuzdak, K.; Niedziałkowski, P.; Bogdanowicz, R.; Sobaszek, M.; Ryl, J.; Weiher, P.; Sawczak, M.; Wnuk, E.; Goddard, W.A.; et al. A Rapid-Response Ultrasensitive Biosensor for Influenza Virus Detection Using Antibody Modified Boron-Doped Diamond. Sci. Rep. 2017, 7, 15707. [CrossRef] [PubMed]

33. Malinowska, N.; Białobrzeska, W.; Łęga, T.; Pałka, K.; Dziąbowska, K.; Żołędowska, S.; Czaczyk, E.; Pala, K.; Nidzworski, D. Antibody Modified Gold Electrode as an Impedimetric Biosensor for the Detection of Streptococcus Pyogenes. Sensors 2020, 20, 5324. [CrossRef]

34. Gray, T.; Alsamman, K.; Murray, E.; Sims, A.; Hupp, T. Engineering a Synthetic Cell Panel to Identify Signalling Components Reprogrammed by the Cell Growth Regulator Anterior Gradient-2. Mol. Biosyst. 2014, 10. [CrossRef]

35. Randles, J.E.B. Kinetics of Rapid Electrode Reactions. Discuss. Faraday Soc. 1947, 1, 11-19. [CrossRef]

36. Białobrzeska, W.; Firganek, D.; Czerkies, M.; Lipniacki, T.; Skwarecka, M.; Dziabowska, K.; Cebula, Z.; Malinowska, N.; Bigus, D.; Biega, E.; et al. Electrochemical Immunosensors Based on Screen-Printed Gold and Glassy Carbon Electrodes: Comparison of Performance for Respiratory Syncytial Virus Detection. Biosensors 2020, 10, 175. [CrossRef]

37. Cebula, Z.; Żołędowska, S.; Dziąbowska, K.; Skwarecka, M.; Malinowska, N.; Białobrzeska, W.; Czaczyk, E.; Siuzdak, K.; Sawczak, M.; Bogdanowicz, R.; et al. Detection of the Plant Pathogen Pseudomonas Syringae Pv. Lachrymans on Antibody-Modified Gold Electrodes by Electrochemical Impedance Spectroscopy. Sensors 2019, 19, 5411. [CrossRef]

38. Niedzialkowski, P.; Slepski, P.; Wysocka, J.; Chamier-Cieminska, J.; Burczyk, L.; Sobaszek, M.; Wcislo, A.; Ossowski, T.; Bogdanowicz, R.; Ryl, J. Multisine Impedimetric Probing of Biocatalytic Reactions for Label-Free Detection of DEFB1 Gene: How to Verify That Your Dog Is Not Human? Sens. Actuators B Chem. 2020, 323, 128664. [CrossRef]

39. Augustine, S.; Kumar, P.; Malhotra, B.D. Amine-Functionalized MoO3@RGO Nanohybrid-Based Biosensor for Breast Cancer Detection. ACS Appl. Biol. Mater. 2019, 2, 5366-5378. [CrossRef]

40. Gajdosova, V.; Lorencova, L.; Kasak, P.; Tkac, J. Electrochemical Nanobiosensors for Detection of Breast Cancer Biomarkers. Sensors 2020, 20, 4022. [CrossRef]

41. Roberts, A.; Tripathi, P.P.; Gandhi, S. Graphene Nanosheets as an Electric Mediator for Ultrafast Sensing of Urokinase Plasminogen Activator Receptor-A Biomarker of Cancer. Biosens. Bioelectron. 2019, 141, 111398. [CrossRef] [PubMed]

42. Negahdary, M. Aptamers in Nanostructure-Based Electrochemical Biosensors for Cardiac Biomarkers and Cancer Biomarkers: A Review. Biosens. Bioelectron. 2020, 152, 112018. [CrossRef]

43. Kilic, T.; Valinhas, A.T.D.S.; Wall, I.; Renaud, P.; Carrara, S. Label-Free Detection of Hypoxia-Induced Extracellular Vesicle Secretion from MCF-7 Cells. Sci. Rep. 2018, 8, 9402. [CrossRef]

44. Nawaz, M.A.H.; Rauf, S.; Catanante, G.; Nawaz, M.H.; Nunes, G.; Marty, J.L.; Hayat, A. One Step Assembly of Thin Films of Carbon Nanotubes on Screen Printed Interface for Electrochemical Aptasensing of Breast Cancer Biomarker. Sensors 2016, 16, 1651. [CrossRef] [PubMed]

45. Luo, L.; Wang, L.; Zeng, L.; Wang, Y.; Weng, Y.; Liao, Y.; Chen, T.; Xia, Y.; Zhang, J.; Chen, J. A Ratiometric Electrochemical DNA Biosensor for Detection of Exosomal MicroRNA. Talanta 2020, 207, 120298. [CrossRef]

46. Tang, Y.; Dai, Y.; Huang, X.; Li, L.; Han, B.; Cao, Y.; Zhao, J. Self-Assembling Peptide-Based Multifunctional Nanofibers for Electrochemical Identification of Breast Cancer Stem-like Cells. Anal. Chem. 2019, 91, 7531-7537. [CrossRef] 